\title{
PENGEMBANGAN MEDIA PEMBELAJARAN PRAKTIKUM VIRTUAL BERBASIS ANDROID UNTUK MENINGKATKAN BERPIKIR KREATIF SISWA
}

\author{
Yeni Suryaningsih*1, Aden Arif Gaffar ${ }^{2}$, Muhamad Kurnia Sugandi ${ }^{3}$ \\ ${ }^{1,2,3}$ Program Studi Pendidikan Biologi, FKIP, Universitas Majalengka \\ e-mail: *11 yenialrasyid@unma.ac.id, ${ }^{2}$ adenarif@unma.ac.id, ${ }^{3}$ kurniasugandi@unma.ac.id
}

\begin{abstract}
ABSTRAK
Penelitian ini bertujuan untuk mengetahui kelayakan dan ketertarikan dari media pembelajaran praktikum virtual berbasis aplikasi android pada konsep materi hewan invertebrata. Penelitian ini merupakan penelitian pengembangan (R\&D) yang mengadopsi model pengembangan Thiagrajan, S., dkk. Menggunakan teknik pengumpulan data non tes berupa angket pakar/ahli media, ahli materi, dan ahli bahasa dan angket respon respon siswa. Hasil penilaian kelayakan media pembelajaran praktikum virtual berbasis androis oleh pakar/ahli media $71,7 \%$ dengan kriteria layak, penilain ahli materi $91,5 \%$ dengan kriteria sangat layak, penilaian ahli bahasa 89,5\% dengan kriteria sangat layak,. Hasil respon siswa sebesar $77 \%$ dalam kategori menarik. Berdasarkan hasil penelitian ini bahwa penegembangan media pembelajaran praktikum virtual berbasis android pada konsep hewan invertebrata dapat dijadikan salah satu alternatif pembelajaran biologi khususnya dalm kegiatan praktikum, serta meningkatkan berpikir kreatif siswa.
\end{abstract}

Kata Kunci : praktikum virtual, media pembelajaran, berpikir kreatif, hewan invertebrata.

\begin{abstract}
This study aims to determine the feasibility and interest of the virtual application learning media based on android applications on the concept of invertebrate animal material. This research is a research and development $(R \& D)$ that adopts the development model of Thiagrajan, S., et al. Using non-test data collection techniques in the form of expert / media expert questionnaire, material expert, and linguist expert and student response questionnaire. The results of the appraisal of androis-based virtual practicum learning media by experts / media experts were $71.7 \%$ with feasible criteria, the assessment of material experts was $91.5 \%$ with very decent criteria, $89.5 \%$ was assessed by linguists as very feasible criteria. Student response results by $77 \%$ in the interesting category. Based on the results of this study that the development of an Android-based virtual practicum learning media on the concept of invertebrate animals can be used as an alternative learning biology, especially preformance practicum activities, as well as increasing students' creative thinking.
\end{abstract}

Keywords: virtual practicum, learning media, creative thinking, invertebrate animals.

\section{PENDAHULUAN}

Saat ini kemajuan teknologi sangatlah pesat, termasuk didalamnya adalah kemajuan dalam penggunaan mobile phone berbasis android. Di kalangan siswa SMA pasti sudah banyak yang menggunakan gawai berbasis android di jaman yang sangat modern ini. Hal tersebut membuat peneliti ingin mengembangkan sebuah aplikasi android yang dapat membantu siswa dalam mempelajari dan memahami materi-materi biologi dengan lebih mudah dan menyenangkan serta lebih bermakna.

Biologi merupakan mata pelajaran yang 
sebaiknya melibatkan keterampilan proses dan proses berpikir melalui metode ilmiah, karena tujuan pembelajaran biologi yakni untuk membekali peserta didik tidak hanya berupa produk melainkan juga proses sains. Oleh karenanya, di abad 21 ini tugas seorang pendidik dituntut untuk lebih sekedar menyampaikan pembelajaran di kelas, namun juga menuntun siswa untuk mengembangkan

keterampilan-

keterampilan yang dimilikinya seperti berpikir kreatif.

Praktikum merupakan metode yang dapat digunakan untuk meningkatkan berpikir kreatif siswa karena indikatorindikator berpikir kreatif dapat diukur melalui adanya kegiatan praktikum. Dengan melaksanakan praktikum, teori-teori yang telah dipelajarinya dapat dibuktikan langsung oleh siswa sehingga mereka mendapatkan pembelajaran yang lebih bermakna sekaligus pengalaman nyata yang menarik.

Akan tetapi, untuk menerapkan metode praktikum dalam pembelajaran yang dapat meningkatkan keterampilan proses sains siswa sering terdapat hambatan, diantaranya yaitu terkait biaya, waktu, dan alat dan bahan laboratorium yang terbatas. Maka untuk mengatasinya, peneliti mencoba inovasi baru dengan membuat aplikasi android berupa praktikum virtual sebagai solusi yang praktis dan mudah digunakan. Kegiatan praktikum virtual sebagai produk dari kemajuan teknologi dapat menjadi solusi alternatif untuk mengatasi hambatanhambatan tersebut. Aljuhani (2018) berpendapat bahwa laboratorium virtual adalah jenis teknologi yang perlu dibawa ke ruang kelas untuk meningkatkan metode pembelajaran di era digital saat ini.

Penggunaan media berbasis android dalam pembelajaran saat ini masih jarang diterapkan, padahal penerapan media tersebut merupakan salah satu pemanfaatan teknologi yang bersifat praktis dalam kegiatan pembelajaran yang sesuai dengan karakteristik revolusi industri 4.0. Dengan demikian, untuk meningkatkan sumber daya manusia di era Revolusi Industri 4.0 ini pendidik dituntut mempunyai kemampuan lebih dalam pemanfaatan teknologi khususnya media digital (Chalim, 2018). Pendapat lain dikemukakan oleh Wurianto (2019) bahwa pembaharuan media pembelajaran yang digunakan merupakan salah satu upaya peningkatan mutu pendidikan yang mempunyai tujuan untuk mengalihkan penggunaan media yang konvensional ke arah penggunaan media pembelajaran yang sesuai dengan perkembangan teknologi dan informasi saat ini di era revolusi 4.0 maupun society 5.0.

Saat ini komputerisasi sudah banyak di implementasikan ke perangkat lain seperti smartphone. Oleh karenanya, dalam era revolusi 4.0 pendidikan di Indonesia harus mampu melakukan loncatan yang lebih maju ke dalam pembelajaran dengan cara memanfaatkan teknologi digital, maka metode praktikum yang tidak dapat dilaksanakan di laboratorium nyata dapat diatasi dengan bantuan media berbasis android berupa aplikasi praktikum virtual yang harapannya dapat digunakan secara efektif untuk melaksanakan praktikum biologi secara virtual. Media praktikum virtual tidak hanya praktis dan menarik tetapi juga dapat memberikan pengalaman yang aman dan menyenangkan dalam kegiatan praktikum.

Penggunaan media praktikum virtual berbasis android mempunyai banyak kelebihan diantaranya yaitu: 1) sangat mudah dioperasikan, 2) memiliki desain yang menarik dan materi yang disajikan sederhana namun mudah dipahami, 3) terdapat soal-soal latihan yang sesuai dengan $\mathrm{KD} / \mathrm{KI}$ dan indikator berpikir kreatif, 4) terdapat laboratorium virtual yang dapat digunakan dan dilengkapi dengan alat dan bahan untuk melakukan kegiatan simulasi atau percobaan layaknya di laboratorium nyata, 5) sangat praktis, yakni dapat dioperasikan dimana saja, 6) tidak bergantung dengan adanya jaringan data karena dapat dimainkan secara offline.

Oleh karenanya, peneliti ingin memberikan inovasi baru dalam pembuatan media pembelajaran yang memanfaatkan teknologi android dengan melakukan penelitian dan pengembangan pembelajaran 
praktikum virtual berbasis android untuk meningkatkan berpikir kreatif siswa pada konsep invertebrata. Pentingnya meningkatkan berpikir kreatif siswa didukung dengan kemajuan teknologi yang sangat pesat dan dibutuhkannya inovasiinovasi baru dalam pemanfaatan teknologilah yang melatarbelakangi dikembangkannnya media pembelajaran dengan inovasi baru yang menggabungkan kegiatan simulasi praktikum dengan aspekaspek kognitif lainnya pada konsep hewan invertebrata yang didukung dengan keberadaan android dengan harapan dapat meningkatkan berpikir kreatif siswa.

\section{METODE}

Jenis metode penelitian ini adalah penelitian dan pengembangan $(\mathrm{R} \& \mathrm{D})$ yang mengadopsi model pengembangan Thiagrajan, S., dkk. (1974). yaitu model 4D meliputi Define, Design, Development dan Dessemination. Alur tahapan penelitian pengembangan 4D secara rinci disajikan dalam gambar 1 berikut:

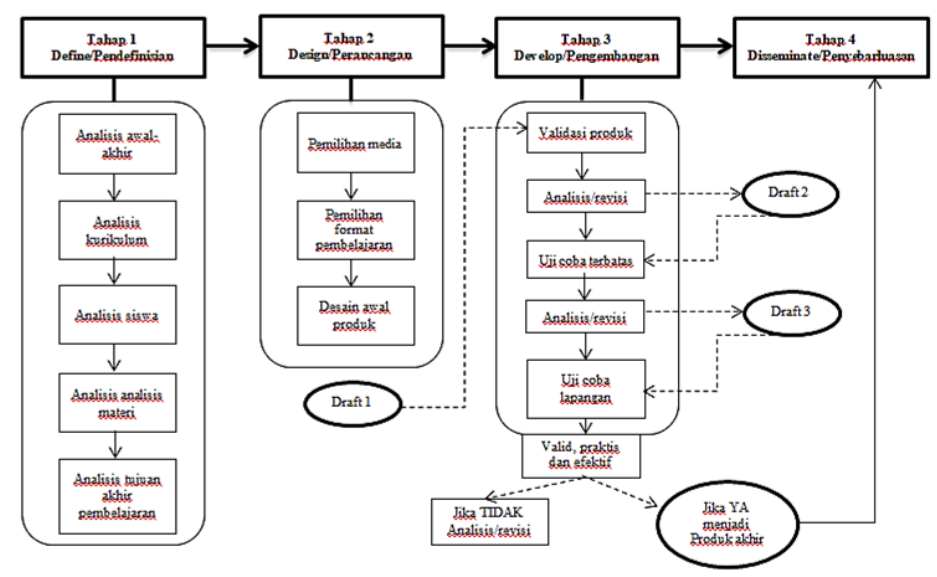

Gambar 1. Model Pengembangan Thiagrajan, S., dkk. (1974).

Konsep penelitian pengembangan yang dikembangkan oleh Thiagrajan, S., dkk. (1974). dapat disederhanakan menjadi studi kualitatif dan studi kuantitatif. Penelitian ini dilaksanakan di SMA Negei 2 Majalengka dengan subjek penelitian kelas $\mathrm{X}$ MIA. Teknik pengumpulan data yang digunakan adalah nontes berupa angket, wawancara dan observasi. Angket terdiri dari angket ahli materi, angket ahli desain media dan angket ahli bahasa, dan angket respon peserta didik.

\section{HASIL DAN PEMBAHASAN}

Pengembangan media pembelajaran beupa aplikasi yang dikembangkan dalam penelitian ini merupakan pengembangan tahap lanjutan yang sebelumnya dekembangkan oleh Gaffar, A.A \& Sugandi, M. K. (2019) berupa aplikasi program yang hanya bisa dioperasikan dalam program komputer. Model Pengembangan pada penelitian ini menggunakan model penelitian Thiagrajan, S., dkk. (1974). Berikut merupakan hasil pengembangan media pembelajaran praktikum virtual berbasis android.

\section{Tahap 1 Pendefinisian}

Praktikum virtual berbasis android merupakan produk yang dikembangakan bertujuan untuk mengatasi permasalahan dalam pembelajaran biologi khusnya pada konsep hewan invertebrata. Praktikum virtual berbasis android dapat dijadikan penunjang dalam kegiatan pembelajaran maupun praktikum disekolah.

Kemudahan penggunaan media aplikasi disesuaikan dengan karakteristik sistem operasi pada gawai, sehingga guru maupun siswa dengan mudah mengoperasikannya.

\section{Tahap 2 Perancangan}

Perancangan $d$ esain awal berupa pembelajaran virtual berbasis komputer 
selanjutnya dilakukan proses pengolahan kode yang menggunakan bahasa pemrograman, dari mulai menuliskannya, memperbaikinya, hingga memeliharanya. Kode yang dimaksud adalah perangkat pembangun suatu program komputer. Sementara itu, bahasa pemrograman adalah suatu stkamur yang berfungsi memberikan perintah kepada komputer. Bahasa jenis ini terdiri dari suatu himpunan dari aturan sintaks dan semantic, sehingga programprogram komputer bisa terdefinisi kedalam sistem operasi di gawai. Pada penelitian pengembangan ini menggunakan Java, Visual Basic, serta Java Script.

Perancangan produk berupa aplikasi media pembelajaran praktikum virtual berbasis android dengan konsep materi hewan invertebrata diharpakan memiliki fungsi kemudahan, tata letak dan konsep serta penggunaan pada gawai.

\section{Tahap 3 Pengembangan}

Tahap pengembangan berupa media pemebelajaran praktikum virtual berbasis android dengan konsep hewan invertebrata selanjutnya dilakukan validasi produk dilakukan dengan cara menghadirakan beberapa pakar atau tenaga ahli meliputi ahli media, ahli materi, dan tenaga ahli bahasa. Berikut deskripsi hasil validasi produk media pemblajaran praktikum virtual berbasis android.

\section{Deskripsi Hasil Validasi Ahli Media}

Pakar/ ahli desain media melakukan validasi media pembelajaran praktikum virtual berbasis android pada konsep hewan invertebrata. Aspek penilaian yang dinilai oleh ahli desain media meliputi; aspek penyajian, aspek grafik, dan aspek kualitas. Bertujuan untuk kelayakan penggunan program pembelajaran layak digunakan. Validasi dilakukan oleh seorang validator ahli desain maupun media pembelajaran merupakan Dosen Program Studi Pendidikan Biologi Fkip Universitas Majalengka. Hasil validasi ahli media yang dapat di lihat pada tabel 1 berikut.

\section{Tabel 1. Tabulasi Hasil Validasi Ahli Media}

\begin{tabular}{lcc}
\hline \multicolumn{1}{c}{ Aspek Penilaian } & Presentase & Kriteria \\
\hline Penyajian & $69 \%$ & Layak \\
\hline Grafik & $72 \%$ & Layak \\
\hline Kualitas & $76 \%$ & Layak \\
\hline Efektifitas & $70 \%$ & Layak \\
\hline Rata-rata Presentase & $71,7 \%$ & \\
\hline Kriteria Kelayakan & & Layak \\
\hline
\end{tabular}

Berdasarkan Tabel 1. Menunjukan bahwa penggunaan media pembelajaran praktikum virtual berbasis android pada konsep hewan invertebrata layak digunakan dalam pembelajaran biolgi. Penilaian oleh validator ahli desain media menunjukan hasil rata-rata presentasi sebesar $71,7 \%$ dengan kriteria layak. Dari hasil tersebut dapat disimpulkan bahwa media pembelajaran prakikum virtual berbasis android layak dan valid untuk dikembangkan dalam tahap berikutnya.

\section{Deskripsi Hasil Validasi Ahli Materi}

Validasi materi dilakukan oleh Dosen Program Studi Pendidikan Biologi FKIP UNMA yang merupakan ahli materi khsusnya konsep hewan invertebra. Hasil validasi ahli materi dapat di lihat dalam tabel 2 berikut. 
Tabel 2. Tabulasi Hasil Validasi Ahli Materi

\begin{tabular}{lcc}
\hline \multicolumn{1}{c}{ Aspek Penilaian } & Presentase & Kriteria \\
\hline Isi Materi & $93 \%$ & Sangat Layak \\
\hline Kebahasaan & $90 \%$ & Sangat Layak \\
\hline Rata-rata Presentase & $91,5 \%$ & \\
\hline Kriteria Kelayakan & & Sangat Layak \\
\hline
\end{tabular}

Berdasarkan Tabel 2. Menunjukan bahwa penggunaan media pembelajaran praktikum virtual berbasis android pada konsep hewan invertebrata sangat layak digunakan dalam pembelajaran biolgi. Penilaian oleh validator ahli desain media menunjukan hasil rata-rata presentasi sebesar 91,5\% dengan kriteria sangat layak. Dari hasil tersebut dapat disimpulkan bahwa media pembelajaran prakikum virtual berbasis android sangat layak dan valid untuk dikembangkan dan sesuai dengan jenjang pembelajaran yang menjadi sasaran pengembangan.

\section{Deskripsi Hasil Validasi Ahli Bahasa}

Program media pembelajaran prakikum virtiual setelah divalidasi oleh ahli media dan ahli materi selanjutnya dilakukan vaidasi oleh ahli bahasa. Hal ini bertujuan untuk melihat kelayakan dari program media pembelajaran praktikum virtual berbasis android dari segi bahasa dapat dipahami oleh pengguna, serta memberikan informasi, masukan, saran dan tanggapan terhadap pengembangan produk.. Aspek penilaian oleh validator yaitu, aspek kualitas penggunaan bahasa dan aspek kesesuaian penempatan kalimat. Validasi ahli bahasa direview oleh dosen dari Universitas Majalengka, yang memiliki spesifikasi bidang kebahasaaan. Hasil validasi dari ahli bahasa dapat dilihat pada tabel 3 berikut.

Tabel 3. Tabulasi Hasil Validasi Ahli Bahasa

\begin{tabular}{lcc}
\hline \multicolumn{1}{c}{ Aspek Penilaian } & Presentase & Kriteria \\
\hline Kualitas Penggunaan Bahasa & $86 \%$ & Sangat Layak \\
\hline $\begin{array}{l}\text { Kesesuain Penempatan } \\
\text { Kalimat }\end{array}$ & $93 \%$ & Sangat Layak \\
\hline Rata-rata Presentase & $89,5 \%$ & \\
\hline Kriteria Kelayakan & & Sangat Layak \\
\hline
\end{tabular}

Berdasarkan Tabel 3. Menunjukan bahwa media pembelajaran praktikum virtual berbasis android pada konsep hewan invertebrata layak digunkan dalam pembelajaran biologi. Penilaian yang meliputi aspek kualitas penggunaan bahasa dan aspek kesesuaian penempatan bahasa memperoleh persentase rata-rata 89,5\% dengan kriteria sangat layak.

\section{Analisis/ Revisi Produk}

Terdapat bebrapa saran dari validator pakar/ahli mengenai produk media pembelajaran praktikum virtual berbasis andorid yang dikembangkan peneliti. Saran dan masukan dari pakar/ahli dapat dilihat pada tabel 4. Berikut. 
Tabel 4. Revisi Produk Berdasarkan Masukan Dari Pakar/Ahli

\begin{tabular}{cl}
\hline Validator Pakar/ Ahli & \multicolumn{1}{c}{ Saran/ Masukan } \\
\hline & $\begin{array}{l}\text { Berdasarkan lembar instrumen lembar validasi } \\
\text { agar menambahkan ciri khas pada tombol } \\
\text { pengaturan serta identitas peneliti, serta } \\
\text { melengkapi sumber pustaka pada setiap gambar } \\
\text { pada setiap materi }\end{array}$ \\
\hline & Berdasarkan lembar instrumen lembar validasi \\
& dapat dilakukan revisi dengan menambahkan \\
Pakar Materi & SK dan KD serta Kelengkapan LKS pada \\
& aplikasi. \\
\hline & Berdasarkan lembar instrumen lembar validasi \\
& dapat dilakukan revisi beberapa kata ada \\
kesalahan tipografi dalam kata maupun kalimat.
\end{tabular}

\section{Uji Coba Terbatas}

Setelah dilakukan validasi pakar/ ahli selanjutnya dilakukan uji coba terbatas produk. bertujuan untuk memperoleh gambaran untuk mngetahui kelayakan serta kualitas dari produk media pembelajaran praktikum virtual berbasis android.
Pelaksanaan uji coba terbatas produk dilakukan terhadap siswa kelas X MIA 4 SMA Negeri 2 Majalengka, dengan kriteria sangat menarik, menarik, tidak menarik. Hasil uji coba terbatas produk yang dapat di interpretasikan pada tabel 5 berikut.

Tabel 5. Hasil Uji Coba Lapangan Terbatas

\begin{tabular}{cccc}
\hline No & Nama Inisial Responden & Persentase & Kriteria \\
\hline 1 & AB & $72 \%$ & Menarik \\
2 & DA & $75 \%$ & Menarik \\
3 & HI & $85 \%$ & Sangat Menarik \\
4 & II & $75 \%$ & Menarik \\
5 & WI & $81 \%$ & Sangat Menarik \\
Rata-rata Persentase & & $77,6 \%$ & \\
Kriteria & & Menarik & \\
\hline
\end{tabular}

Berdasarkan Tabel 5. Hasil uji coba lapangan terbatas memperoleh rata-rata persentase sebesar 77,6 \% dengan kriteria menarik. Berasarkan hasil tersebut, pengembanagan media pembelajaran praktikum virtual berbasis android disukai responden dan tidak membosankan serta responden bisa belajar dimanapun dan kapanpun.

\section{Revisi Hasil Uji Coba Terbatas}

Revisi hasil uji coba terbatas diantaranya ada beberapa saran dari responden yaitu, ukuran aplikasi yang terlalu besar sehingga ada beberapa responden yang memiliki gawai dengan kapasitas penyimpanan yang kecil tidak bisa dilakukan pemasangan program aplikasi media pembelajaran praktikum virtual.

\section{Uji Coba Lapangan Sekala Luas}

Setelah dilakukan uji coba sekala terbatas, selanjutnya dilakukan uji coba lapangan sekala luas. Pelaksanaan uji coba terbatas produk dilakukan terhadap siswa kelas $\mathrm{X}$ MIA 2 SMA Negeri 2 
Majalengka mrlibatkan 20 responden, bentuk penilian dengan kriteria sangat menarik, menarik, tidak menarik. Pemilihan responden dilakukan secara acak. Hasil uji coba sekala luas diperoleh rata-rata persentase sebesar $77 \%$ dengan kriteria menarik. Responden merasa terbantu dengan adanya aplikasi media pembelajaran yang terpasang pada gawai, komentar tersebut berdasarkan kemudahan penggunaan yang sangat sesuai dengan kemajuan teknologi sesuai dengan revolusi industri pendidikan 4.0. Hasil uji coba lapangan sekala luas dapat di interpretasikan pada tabel 6 berikut.

\section{Tabel 6. Hasil Uji Coba Lapangan Sekala Luas}

\begin{tabular}{cccc}
\hline No & $\begin{array}{c}\text { Nama Inisial } \\
\text { Responden }\end{array}$ & Persentase & Kriteria \\
1 & A & $70 \%$ & Menarik \\
2 & B & $75 \%$ & Menarik \\
3 & C & $80 \%$ & Sangat Menarik \\
4 & D & $75 \%$ & Menarik \\
5 & E & $85 \%$ & Sangat Menarik \\
6 & F & $85 \%$ & Sangat Menarik \\
7 & G & $79 \%$ & Menarik \\
8 & H & $75 \%$ & Menarik \\
9 & I & $80 \%$ & Sangat Menarik \\
10 & J & $75 \%$ & Menarik \\
11 & K & $65 \%$ & Menarik \\
12 & L & $70 \%$ & Menarik \\
13 & M & $75 \%$ & Menarik \\
14 & N & $80 \%$ & Sangat Menarik \\
15 & O & $85 \%$ & Sangat Menarik \\
16 & P & $90 \%$ & Sangat Menarik \\
17 & Q & $65 \%$ & Menarik \\
18 & R & $75 \%$ & Menarik \\
19 & S & $80 \%$ & Sangat Menarik \\
20 & T & $75 \%$ & Menarik \\
\cline { 1 - 2 } Rata-rata Persentase & $77 \%$ & \\
Kriteria & & Menarik & \\
\hline \multicolumn{5}{r}{} & & & \\
\hline
\end{tabular}

Penelitian pengembangan ini menghasilkan berupa produk media pembelajaran praktikum virtual berbasis android pada konsep hewan invertebrata. Produk berupa aplikasi yang dapat di pasang pada gawai siswa dapat memudahkan pembelajaran praktikum biologi khususnya konsep hewan invertebrata, dimana guru dan siswa tidak harus mencari bahan praktikum dikarenakan sudah ada dalam aplikasi. Selain itu aplikasi yang digunakan dapa dioperasikan secara off line dengan kata lain tidak harus memerlukan jaringan internet. Penelitian yang dilakukan oleh Litasari, dkk (2014) menyatakan bahwa program praktikum virtual sebagai penyedia animasi dan tiruan lingkungan laboratorium dengan terdapat alat dan bahan, sehingga dapat dijadikan media alternatif yang digunakan di rumah mereka masing- 
masing. Menurut Gaffar, A.A \& Sugandi, M. K. (2019) Dapat. menjadikan inovasi teknologi dalam pembelajaran yang dapat diajdikan sebagai alternatif dalam menyelesaikan kekurangan dan hambatan dalam pembelajaran khusnya kegiatan
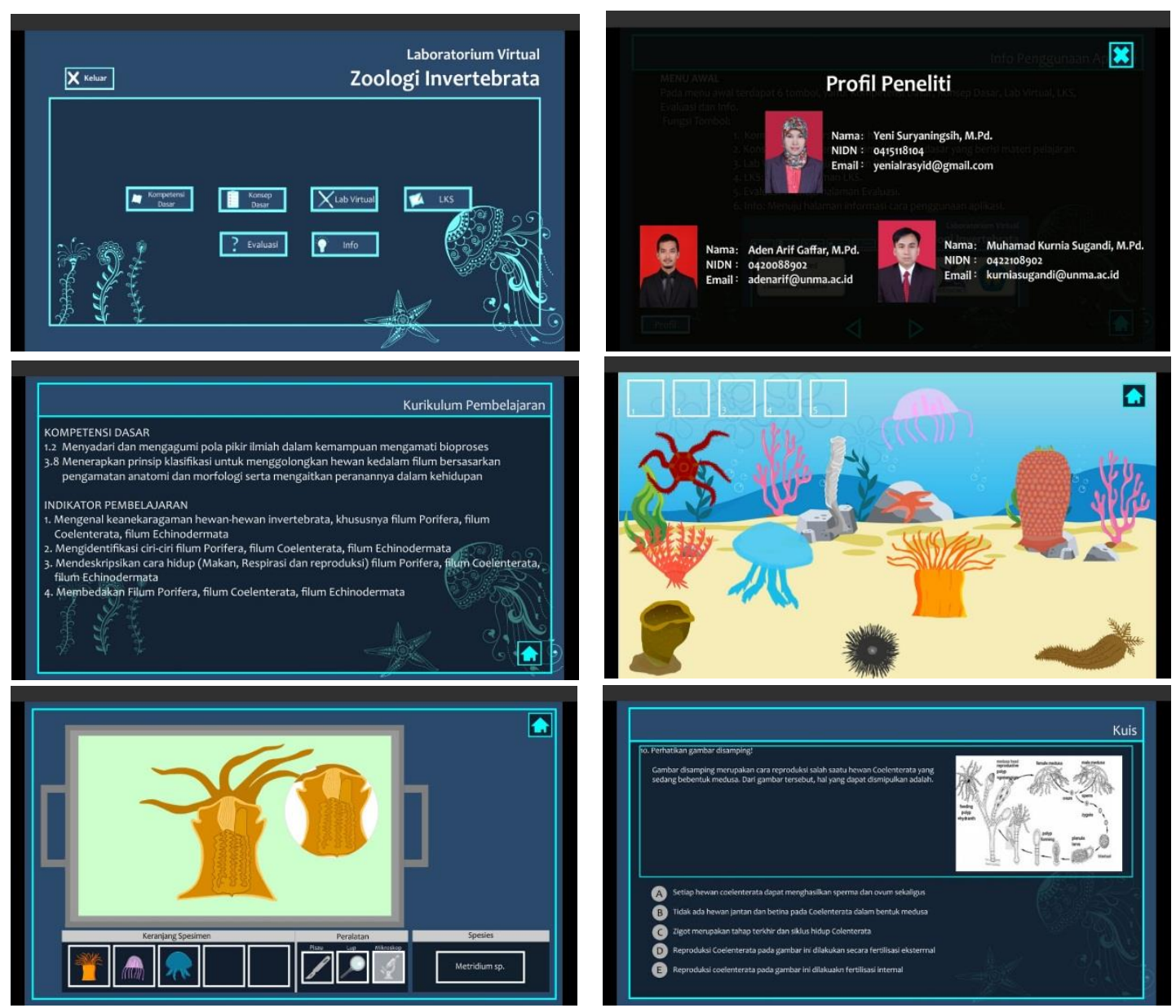

Gambar 2. Aplikasi Praktikum Virtual Berbasi Android

\section{KESIMPULAN}

Simpulan dari penelitian ini bahwa penegembangan media pembelajaran praktikum virtual berbasis android pada konsep hewan invertebrata dapat dijadikan salah satu alternatif pembelajaran biologi khususnya dalm kegiatan praktikum, serta merupakan sebuah inovasi bentuk pembelajaran yang sesuai dengan perkembangan di era revolusi industri pendidikan 4.0. praktikum. Tampilan aplikasi praktikum virtual yang dapat dilihat pada gambar 2 berikut. 
Science Lab (VSL): the adoption of virtual Labs in Saudi schools. Smart Learning Environments.

Chalim, Saifuddin. 2018. Strategi Lembaga Pendidikan Menghadapi Tantangan Masa Kini. Jurnal Pendidikan Islam.

Dahar, R. W. (1989). Teori-teori Belajar. Jakarta. Erlangga

Ekskresi dalam Meningkatkan Motivasi Belajar Siswa SMA. Jurnal Pendidikan Sains, 4(4), 130-136.

Fraenkel, J. R. Dan Wallen, N.E. (2007). How to design an Evaluate Research in Education. New York: McGrawHill Companies.

Litasari, K. N., Setiati, N., \& Herlina, L. (2014). Profil Pembelajaran Biologi Berbasis Laboratorium dan Implikasinya Terhadap Hasil Belajar Siswa di SMA Negeri Se-Kabupaten
Semarang. Journal of Biology Education, 3(2).

Wurianto, Arif, Budi. 2019. Literasi Bahasa dan Sastra Indonesia Menuju Kewirausahaan Profesi Di Era Revolusi Industri 4.0 dan Society 5.0 (Peluang dan Tantangan). Prosiding SENASBASA.

Gaffar, A. A., \& Sugandi, M. K. (2019). PENGEMBANGAN MEDIA PERANGKAT PEMBELAJARAN BERBASIS PRAKTIKUM VIRTUAL UNTUK MENINGKATKAN KETRAMPILAN PROSES SAINS SISWA SMA. Jurnal Biotek, 7(2).

Thiagarajan,S., Semmel, D.S., \& Semmel, M.I. 1974. Instructional Development for Training Teacher of Exceptional Children. Reston: Sourcebook. 